\title{
The Domestic Governance Countermeasure in Order to Enhance
}

\section{Soft Power of China Communist Party}

\author{
Yuzhi Zhang \\ School of Politics, Qufu Normal University, Rizhao Campus \\ Rizhao 276826, China \\ E-mail: zyz911@yeah.net
}

Zhongfu Jiang

Department of Economic and Legal Affairs, Shandong Electric Power Group Corporation

Jinan 250001, China

\begin{abstract}
The Chinese Communist Party is facing many problems in domestic governance. E.g. livelihood issues, corruption and so on. These issues will be solved by the ruling party's effective domestic governance in soft power which achieves the purpose to enhance the soft power of Chinese Communist Party.
\end{abstract}

Keywords: Countermeasure, The Chinese Communist Party, Soft power, Domestic governance

\section{The Chinese Communist Party is facing the problems of domestic governance}

China lies in a stage of critical historical transition after we have implemented the reform and opening-up policy for 30 years. The economic problem of poverty in the previous stage has been effectively resolved so that national life is greatly improved and the country's international status increases significantly. However, the old problems are no longer prominent, new problems arise. Nobody will think that the problems are getting less and less, but there are more and more problems in front of the Chinese Communist Party. These questions are described below:

First, it is the problem of corruption. It is a serious problem for from the high-ranking officials to ordinary people. Chinese Communist Party official corruption seriously tarnished the reputation of the ruling party and the political image, making their soft power weaken. According to statistics, the average amount of corruptive officials involved 35.0643 million Yuan, the average amount of bribes was 2.5329 million Yuan in 2007; the average amount of money involved was 1026.7745 million, the average amount of bribes was 884.1073 million in 2008.(2009) According to another report, Lipo County, Wenshan Chuang nationality and Miao nationality Autonomous Prefecture in Yunnan Province, former county party secretary Zhao Shiyong lost his power because of corruptive money of nearly five million Yuan, known as the most corruptive county party secretary in our country. More million goods such as Color TV, purses and watches, and a few dollars of goods such as washing products, socks, etc., Zhao Shiyong wrote off as public funds openly. (2010) Huge amount of corruption, involving many departments and the number of the people, is really unprecedented, and the trend intensifies, resulting in many grievances. Corruptive officials not only make people hate them, the most frightening thing is the ruling idea of corruptive officials. Zhao Shiyong said: "While some companies had achieved good efficiency, gave me some money on New Year's Day or other festivals, I was grateful and very proud. As enterprises developing, there was a good benefit so that they sent some money. I collected them and felt at ease and justified, which was my values. "This sentence was explained in simple words: business development had my credit, I accepted the bribery in peace of mind, a sense of pride and achievement rising in the chest. (2010) This value overturned the correct ruling idea of Communist Party of China. It can be said that, the Chinese Communist Party would be in a real danger which was losing the power and itself if corruption was not kept in limits. These words were not scaremongering.

Second, it is the problems of people's livelihood. I.e. the issues were bound up with people's lives, especially concern to the public. Specifically these includes medical treatment (can not go to see a doctor), education (can not go to school), housing (no fixed abode, can not afford a room), and the large gap between the wealthy and the poor and so on. In recent years, most people have been concerned that the gap between the rich and the poor is becoming larger and larger. The rich are becoming richer, and the poor are getting poorer. The Boston 
consulting firm released the "2006 World Wealth Report" in May 2007 which noted that $0.4 \%$ of families held $70 \%$ of the national wealth in China; it was $5 \%$ of households control $50 \%-60 \%$ of the country wealth generally in Japan, Australia and other mature markets.(Honggang Han,2009) Concentration of wealth can be seen in China. China has become the most highly concentrated wealth country in the world. China's wealth concentrated to the rich with an average acceleration $12.3 \%$ every years which was 2 times the growth of the global average growth .(Honggang Han, 2009) According to the data of a joint investigation report from the State Council Research Office, Research Office of the Central Party School, the Central Propaganda Department Research Center, Chinese Academy of Social Sciences and other departments, there was 27,310 people that their private ownership of property in Mainland China (not including the outside foreign property) was more than 50 million Yuan, and there was 3220 people that their property was more than 100 million Yuan at the end of March 2006. 2932 people were children of senior cadres among 3220 people. They accounted for $91 \%$ of billion households, with assets of more than 20,450 billion. Their assets mainly relied on family background so that those were power capital. (Honggang Han, 2009)The widening gap between the rich and the poor relates with the concentration of power in China, which worsen the social and political environment in China's domestic governance and which greatly weaken the ruling party's soft power. The Chinese Communist Party's social base has been shaken. Aristotle once said: "If a regime was missing the middle class, the poor lied in absolute advantage in numbers, then the civil strife would soon happen, then city also attributed to the disintegration." (Aristotle, 2003, pp.139-140) Communist Party of China does not want to see Chinese society disintegrate, as did the Soviet Union; CCP must solve those serious social problem and political problems. Communist Party of China's domestic governance issues have many, not listed, out of question, these issues weaken the ruling party's soft power to some extent. Solving the problem and prompting the ruling party's internal governance more reasonable, we must take the following measures.

\section{The Domestic Governance Countermeasure in Order to Enhance the Soft Power of China Communist Party}

The major issues are placed in front of the Chinese Communist Party, some serious damage to the reputation of the party, some threatening the legitimacy of the party's ruling status, while others are related to the survival of the party. No matter what question the Chinese Communist Party needs to face the reality rather than to avoid the problem, adjust the power of thinking, update concept of governance. CCP continue to explore the relevant measures to solve the problem by the use of the international advanced governance theories.

First, CCP establish and maintain correct political values, and expand public recognition of the ruling philosophy. Joseph Nye firstly brought forward the theory of soft power. He often mixed ideas, political values and ideology in his theory." (Zhang Xiaoming, 2005, p.24) He didn't make a clear distinction between the three precise meanings. After all, we can consider that the three concepts emphasize the mainstream ideology of the ruling party. The ruling Chinese Communist Party itself understand the nature and historic tasks of the party's governing, correct attitude of the ruling, establish the right ruling values. Communist Party of China is from the people, rooting in the people, serving the people, so that the party's tasks and responsibilities is to realize the fundamental interests of the people. The mainstream Values of the ruling could be no ambiguity; it is important contents to keep the ruling party's soft power. From the beginning, the Chinese Communist Party consciously looks itself as a tool to realize the interests of people, and always adhere to the founding and governing for the people. CC P' struggle of 80 years, whether bloody war to overthrow the "three big mountains", or the establishment of the socialist system including carrying out large-scale socialist construction, reform and opening up and socialist modernization, its final purpose is to protect, develop, and realize the fundamental interests of the overwhelming majority of people. Chinese leaders have had a brilliant exposition about this point. Mao Zedong made it clear in the new democratic revolution; our party "should have the most majority Chinese people's interests in mind", "all the words and deeds of the Communists must be in line with the overwhelming majority of the best interests of the people, for the masses' support was the highest standard. " (Mao Zedong, 1991, p.1096) Deng Xiaoping had said clear: the party" was the people's wholehearted servicers and it reflected the interests and will of the people, and effort to help people organize themselves for their own interests and will. “(Deng Xiaoping, 1994, p.218) Jiang Zemin profoundly pointed out in summing up the party's struggle of eight years:" serving the people wholeheartedly, Power for the People, was the fundamental difference between our party and the exploiting class. " (Jiang Zemin, 2001, p.505)Hu Jintao also stressed: "'Three Represents' essence was reigning for the People," "to achieve the aspirations of the people, to meet the needs of the people and to safeguard the interests of the people was the 'Three Represents' important thought the fundamental starting point and purpose." (Hu Jintao, 2003) The ruling party's power came from the people specifically, Hu said: "the ruling party's ability and status came from the people fundamentally, and the people's support was the most solid 
political foundation and the most profound source of strength for the party." (Hu Jintao, 2005) These conclusions show that the Chinese Communist Party has a profound understanding on the relationship between officials and the public.

Chinese ancient sages had a clear understanding about on the relations between the public and officials. "Monarchs are boat; common people are water. Water carries boat, the water will overturn it." (Xunzi, 2003, Monarch reign) People's political choices will still change once they determine from the basic rules of political development. The ruling party fulfills its promise and people's interests to some extent, and the people support the ruling party to some extent. Whether the ruling party comes into power in the long run depends on the masses of the people identification with the values of the ruling party.

In other words, the ruling party wants to win the trust and support, it must look the people's interests as the fundamental starting point and purpose, governing for the people and enhancing the identity of political values. The ruling party would be abandoned by the people ultimately if the ruling party ignored the long-term interests of the people. In this sense, the people will determine the fate of the ruling party. Summarizing the painful lessons of the long-ruling Communist regime which lost the power, Jiang Zemin pointed out: "a regime or a party, its future and fate depended on popular support. It would collapse inevitably if it could not win the most support from the masses." (2003, p.115)

Second, innovating and sounding system construction, controlling corruption effectively. It is the biggest danger for the ruling party to lose the people's support. Corruption makes the ruling party separate itself from the people. The serious corruption is enough to destruct a country. "Look the state and family, the thrift makes them succeed while the extravagance makes them fail."(Li Shangyin: "Ode to History", 1999, vol 539) The problem of corruption in Chinese society not only harms the interests of the majority of the people, undermining the ideal of a harmonious socialist society, but also makes the distance between the Chinese Communist Party and the people larger, to weaken the credibility and soft power of the Chinese Communist Party, even the loss of national sovereignty. So, if CCP wants to maintain and enhance the soft power of the ruling party, it must prevent and control corruption, with a resolute struggle against corruption. Hu Jintao stressed: "the nature and purpose of the Chinese Communist Party decided that the party was incompatible with a variety of corrupt phenomena. Resolutely punishing and effectively preventing corruption, relating with the party's survival, was the party's major political task. "(Hu Jintao, 2007) The Chinese Communist Party is gradually shifting from fighting corruption by power to by the system at the current in the way of anti-corruption. Deng Xiaoping said "the system could prevent bad people do bad things; the bad system had the good people do bad things." He is the precursor using the system to fight corruption in the party. Use foreign common practice to curb corruption effectively. Property reporting system is an important innovation. Overseas experience has proved successful, officials of property reporting system is the most fundamental institutional anti-corruption protection. Officials' corruption scandals have occurred in the United States, but at a relatively low level for a long time because of the establishment of a strict property reporting system. So the party adopts the world's common property declaration system. Wen Jiabao mentioned the implementation of property declaration system was an important measure for anti-corruption, and said, "To implement government affairs open including the official property open should do the real thing without going through the motions. We must establish a system and legislation, and maintained it for long time. It would achieve the desired effect. We were actively preparing for this work." (Wen Jiabao, 2009) This fully demonstrates that CCP's senior officials attach importance to the system of anti-corruption.

In addition, various types of supervision should be strengthened so that the ruler of all powers is in the sunshine except that innovative system constraints the corruption. British historian Lord Acton once said: "Power tends to corrupt, absolute power cause absolute corrupts." In 19th century (Lord Acton, 2001, p.1) so the ruling party must accept all kinds of supervision, including internal supervision, external supervision and social supervision and so on. We should pay more attention to social supervision and external supervision, because the monitoring main body is the vast number of ordinary people in all kinds of supervision. In contemporary society, such external monitoring force can not be ignored in curbing corruption, including a variety of media and public opinion, especially the network monitoring which is a very effective means of supervision in China. The Chinese Communist Party intends to take the network supervision as an important anti-corruption measure. Internet users have the rapid growth in China in the information age. According to "the 24th China Internet Development Statistics Report" revealed that the scale of China's Internet users had reached 338 million in June 30, 2009. The users representing the new social forces are increasingly active in monitoring, and often play an important role in fighting corruption. The ruling party wants to curb corruption momentum but the monitoring system is not perfect in the case. CCP need to take the advantage of the network supervision so that ordinary people have their own political voice through the network breaking the power elite's monopoly on the media. The network 
supervision has a good broad representation so that the true will of the people and views are fully expressed. As the network monitoring and system supervision continue to coordinate, the network supervision will be a sword to solve corruption problems.

Thirdly, CCP carries on civil and political construction, making efforts to solve "the problem after development." Deng Xiaoping had ever reflected on the developing road and thought that the problems were more than ones before the developing. He stressed: "This problem (how to distribute the wealth) must be solved" though "to solve this problem was more difficult than to solve the developing problem." "To use every means and ways solve a variety of these problems." Otherwise," one day the problems develop." (Deng Xiaoping, 2004, p.1364) These problems are related to specific livelihood issues such as health, education, housing, etc.; there is social injustice in the process of social distribution of benefits; mass incidents have happen frequently and distributed widely; there is the problem of the vulnerable groups and so forth, The problems after developments and development issues are in different historical periods. The former relate with the evolution of public values in the transformation of society, but more importantly, those in power emphasize economic policy and ignore the fundamental social policy. China enters the transitional period which increase social stratification and mobility. The economic interest main body appears diversification and there has profound changes in social structure. Conflicts and contradictions about the interests of society are unprecedented sharp and intense. These problems are not terrible; the key is the ruling party's thinking, ideas and models to solve the problem for improvement. For example, the mass incidents are more prominent in China's economic development. According to data provided by the concerned departments show that the number of mass incidents increased sharply from 1994 to 2003, the annual average increase 17\%, from 1 million cases in 1994 increased to 6 million cases in 2003, an increase of 5 times; the number of participants have been expanding by $12 \%$ annual growth, increasing from 73 million to 307 million; the number and scale of mass incidents has never seen a few years ago in China in 2004. (Gao Huacheng, 2006, p.256) The mass incidents are the nature of class struggle simply in traditional rule-based thinking, which should be severely punished; or that thing is abetted by a few people and put the government's responsibility directly onto the so-called "minority." A lot of mass incidents have been often taken a negative and even violent disposal in this simple and rigid thinking, resulting in intensification of contradictions and tragedies. To resolve mass incidents, the key is to uphold the service-oriented way of thinking, abandoning the traditional authoritarian governance model.

For now, the Chinese Communist Party not only explores some positive and useful measures to solve the problem but also achieves some good results. CCP have implemented some policies of benefiting the people and really bring tangible benefits to the people. E.g. the end of agricultural tax, grant subsidies for growing grain, raising the enthusiasm of farmers farming; free nine-year compulsory education, expanding the range of educational subjects; to implement the new rural cooperative medical system to solve rural health issues and so on. These policies have been widely welcomed and benefited the people. However, these policies are not enough with the development of China; need to continue to improve people's living standards so that ordinary people enjoy the prosperity of the country and the development results.

\section{Conclusions}

The Chinese Communist Party's domestic governance, not merely use the means of hard power, because of this, not only ineffective, there's likely to intensify social contradictions in the 21 st century. Using soft power to control and effectively containing corruption, expanding the recognition of political ideas of the ruling party, addressing the livelihood issues of the general public in order to promote social fairness and justice and tends to harmony in the process of governance. This requires construction of the soft power of Chinese Communist Party to enhance the attractiveness of the ruling party.

\section{References}

Acton. (2001). Freedom and Power. Hou, Jian and Fan, Yafeng translated. Beijing: Commercial Press. p1.

Aristotle. (2003). Political Science. Yan, Yi and Qin, Dianhua translated. Beijing: Chinese People University Press. pp139-140.

Central Committee Propaganda Department. (2003). The Learning Platform of "Three Represents' Important Thought. Beijing: Learning Press.p115.

China's corruption statistics: average bribes of 9 million Yuan more than 3 times in 2007. (2009). Legal Evening News. February 23.

Deng, Xiaoping. (1994). Deng Xiaoping's Selected Works (Vol. I). Beijing: People's Publishing House.p218. 
Deparment of Culture of Shandong Province. The subject of "soft power and harmonious society." The medium-term results. Project number:20080083.

Gao, Hua Cheng. (2006). National Security of China's "Peaceful Development". Beijing. PLA Foreign Language Audiovisual Publishing House. p256.

Han Honggang. (2009). $0.4 \%$ of the population possesses $70 \%$ of the wealth and the division between the rich and the poor sharply increases. Die Zeit. June 25, 2009.

http://news.xinmin.cn/rollnews/2010/04/21/4544624.html. (April 24, 2010).

$\mathrm{Hu}$, Jintao. (2005). The Speech of Chinese Communist Party the Sixteenth Central Commission for Discipline Inspection the Fifth Plenary Session. People's Daily. January 12, 2005.

Hu, Jintao. (2007). Holding High the Great Banner of Socialism with Chinese Characteristics to Win New Victories in Building Moderately Prosperous Society - the Report of the 17th National Congress of the Communist Party. The Chinese government network, [Online] Available: http://www.gov. cn/ldhd/2007-10/24/content_785431_12.htm (April 22, 2010).

Hu, Jintao. (2003). The Seminar Speech of "Three Represents" Theory. People's Daily. July 2, 2003.

Jiang, Zemin. (2001). On the Construction of the Party. Beijing: Central Literature Publishing House.P505.

Kunming Daily. April 18, 2010.

Leng, Rong. (2004). Chronicle of Deng Xiaoping (below). Beijing: Central Literature Publishing House. p1364.

Li, Shangyin. (1999). Full Tang. Beijing: Zhonghua Book Company.

Mao, Zedong. (1991). Mao Zedong Selected Works (Volume III). Beijing: People's Publishing House.p1096.

The values of "socks corrupt officials" are terrible.

Wen, Jiabao. (2009). The Establishment of Official Property Declaration System is the Major Anti-corruption Initiatives. [Online] Available: http://politics.people.com.cn/GB/1024/8885385.html (April 20, 2010)

Xun, Kuang. (2003). Xun Zi Translation and Annotation. Gao, Changshan translated. Harbin: Heilongjiang People's Publishing House.

Zhang, Xiaoming. (2005). An Analysis of Joseph Nye's soft power Concept. American Studies Qquarterly. (1).pp.20-36. 